Journal of the Egyptian Society of Parasitology, Vol.43, No.2, August 2013

J. Egypt. Soc. Parasitol., 43(2), 2013: 387 - 398

\title{
MONTHLY ABUNDANCE OF RODENT AND THEIR ECTOPARASITES IN NEWLY SETTLED AREAS, EAST OF LAKES, ISMAILIA GOVERNORATE, EGYPT
}

\section{By}

IMAN M. BAHGAT

Department of Zoology, Faculty of Science, Port Said University, Egypt

\section{Abstract}

Rodents and their ectoparasites were studied inside and outside houses in the newly settled areas, east of lakes, Ismailia Governorate, Egypt. Forty traps per month in each of the two sides were used for collecting rodent during 2009. From 221 rodent were collected from inside houses; Mus musculus $\mathrm{N}=115$ (52.04\%), Rattus rattus. frugivorous $\mathrm{N}=54(24.43 \%), R$. $r$. alexandrinus $\mathrm{N}=40(18.10 \%)$ and $R$. norvegicus $\mathrm{N}=12(5.43 \%)$. From 177 rodent were collected from outside houses; M. musculus $\mathrm{N}=4(2.3 \%), R$. $r$. frugivorous $\mathrm{N}=29$ (16.43\%), $R$. $r$. alexandrinus $\mathrm{N}=37(20.9 \%), R$. norvegicus $\mathrm{N}=36$ (20.3\%), Gerbillus pyramidum $\mathrm{N}=67(37.9 \%)$ and Jaculus jaculus $\mathrm{N}=4$ (2.3\%). Total ectoparasites per rat inside houses were 765 $(3.46 \mathrm{E} / \mathrm{Rat})$ which were classified as fleas, $\mathrm{N}=464(2.11 \mathrm{~F} / \mathrm{R})$; lice $\mathrm{N}=150(0.68$ $\mathrm{L} / \mathrm{R})$ and mites $\mathrm{N}=151(0.68 \mathrm{M} / \mathrm{R})$. From outside house, total ectoparasites per rat were $984(5.5 \mathrm{E} / \mathrm{R})$ which were classified as fleas, $\mathrm{N}=410(2.31 \mathrm{~F} / \mathrm{R})$; lice $\mathrm{N}=100$ $(0.56 \mathrm{~L} / \mathrm{R})$, mites $\mathrm{N}=400(2.23 \mathrm{M} / \mathrm{R})$ and ticks, $\mathrm{N}=74(0.42 \mathrm{~T} / \mathrm{R})$. From indoors two fleas species were recorded (Xenopsylla cheopis and Ctenopsyllus segnis); one species of lice (Polyplax spinulosa) and four species of mites (Laelaps nuttall, Ornithonyssus bacoti, Dermanyssus gallinae and Eulaelaps stabularis).

The outdoors ectoparasites were; six fleas species (X. cheopis, X. ramesis, Pulex irritans, C. segnis, Stenoponia tripectinata and Nosopsylla sinaiensis); one lice species ( $P$. spinulosa); Six mites species (L. nuttalli, O. bacoti, D. gallinae, E. stabularis, Haemogamasus pontiger and Hirstionyssus isabellinus) and immature stages of two ticks species (Rhipicephalus sp. and Hyalomma sp.). Most of these ectoparasites were recorded infesting G. pyramidum.

Keyword: Egypt, Ismailia Governorate Rodents, Ectoparasites, Newly settlement.

\section{Introduction}

The several ambitious developmental programs have been planned and started in east of the Suez Canal lakes, Ismailia Governorate. More than 500,000 acres were reclaimed; cultivated and new villages were built in this desert and supplied with regular supply of water from the Nile. The goals of these newly reclaimed area are cultivation of 1000,000 acres and establishment of 35 new village settlements of 5000,000 inhabitants most of them young graduates coming from the Nile Delta. The ecosystem of these new areas will certainly be affected and changed as a re- 
sult of extensive agricultural and other civic activities of the new settlers during the coming years. Therefore much efforts and researches are needed to avoid the creation of new epidemicity of zoonotic diseases in this area.

The rodents are mainly reservoirs for many disaster diseases, infested with many ectoparasite-vectors (Shoukry et al, 1991; El Kady et al, 2007; El Bahrawy et al, 2008). They play an important role in diseases transmission to human or animals (Morsy et al, 1988; Shoukry et al, 1993; El Kady et al, 1995; Reeves et al, 2007). Rodents are real factor markedly affecting human health and welfare (El Gindy et al, 1987). They have followed man to all parts of the world carrying to him the dangerous zoonotic diseases. These are too much to tell as plague, murine typhus, rickettsial diseases (Abdou and Samaan, 1962; Shoukry et al, 1993; Reeves et al, 2007) cutaneous leishmaniasis (Morsy et al, 1982, 1987; El Kady et al, 1998) trichinosis (Morsy et $a l, 2000$ ), toxoplasmosis (Rifaat et al, 1978) and others. Man is infected with the diseases by contact or by their ectoparasites.

The work aimed to study the monthly abundance of rodents and their arthropods ectoparasites from inside and outside houses in newly settled areas, east of lakes, Ismailia Governorate, Egypt.

\section{Materials and Methods}

The present study was carried out in El Takadom village, east of lakes, Ismailia Governorate, located at $30^{\circ} 37$ $\mathrm{N} \& 32^{\mathrm{O}} 22 、$ E. Rodents were trapped alive from inside and outside houses.
Monthly visits were made alternatively to one of the two sides of the village over one year period extending from January to December 2009. A total of 40 wire box traps were used to collect rodents. The rodents were anesthetized with the least amount of chloroform and were identified by sex and species according to standard keys (Osborn and Helmy, 1980; Morsy et al, 1988). The ectoparasites were carefully collected by brushing the animal with a stiff-hair brush. The ectoparasites of each rodent were preserved separately in $70 \%$ ethanol in labeled specimen tubes. Ectoparasites were mounted as usual and identified by species. Ectoparasites identification; fleas, lice, ticks and mites were done after the international keys (Lewis, 1967; Hubbard; 1947; Hoogstraal, 1956; Baker et al, 1956). Indices calculation: rat index=number of trapped rat/ trap/night. General index of an ectoparasite on a given rat host $=$ number of an ectoparasite on rats of same species/total number of collected rats belonging to the same species. Data were analyzed using one way ANOVA test.

\section{Results}

A total of 221 rats were captured from indoors during the study period which extended from January to December 2009 (Tab. 1). Out of these $M$. musculus $\mathrm{N}=115$ (52.04\%), R. r. frugivorous $\mathrm{N}=54(24.43 \%), R$. $r$. alexandrinus $\mathrm{N}=40(18.10 \%)$ and $R$. norvegicus $\mathrm{N}=12$ (5.43\%). Mus musculus was the most dominant rodent species. Significant temporal variations were recorded in rodents densities trapped from indoors $(\mathrm{F}=6.845607 ; \mathrm{P}=0.01)$. The highest rat index was recorded in Au- 
gust (0.68 rat/ trap) while the lowest was recorded in January (0.28 rat/trap).

A total of 765 ectoparsites were recovered from different rodent species trapped indoors. Highest total ectoparasite index (10.42 ectoparasite /rat) was on $R$. norvegicus while lowest (1.869 ectoparasite/rat) was recorded on $M$. musculus. The recovered ectoparasites were two fleas species $X$. cheopis and C. segnis $(\mathrm{n}=464,60.65 \%)$ one louse, P. spinulosa $(\mathrm{n}=150,19.6 \%)$ and four mites, L. nuttalli, O. bacoti, D. gallinae \& E. stabularis $(\mathrm{n}=151,19.74 \%)$. Maximum ectoparasites indices were on $R$. norvegicus, which were 3.67 flea/rat for $X$. cheopis, 3.17 lice/rat for P. spinulosa and $1.58 \mathrm{mite} / \mathrm{rat}$ for D. gallinae.

Table 1: Monthly abundance of rodents collected from indoors at east of lakes, Ismailia Governorate over the year 2010:

\begin{tabular}{|l|c|c|c|c|c|c|c|}
\hline \multirow{2}{*}{ Month* } & \multirow{2}{*}{$\begin{array}{l}\text { Rodents } \\
\text { Number }\end{array}$} & $\begin{array}{l}\text { Rodent } \\
\text { Index ** }\end{array}$ & $\begin{array}{l}\text { M. } m . \\
\text { muscuslus }\end{array}$ & $\begin{array}{l}\text { R. } r . \\
\text { frugivorous }\end{array}$ & $\begin{array}{l}\text { R.r. } \\
\text { alexandriuns }\end{array}$ & $\begin{array}{l}\text { R. } \\
\text { norvigicus }\end{array}$ & \multirow{2}{*}{} \\
\hline Jan. & 11 & 0.28 & 6 & 2 & 3 & - & 4.98 \\
\hline Feb. & 12 & 0.30 & 6 & 2 & 4 & - & 5.43 \\
\hline Mar. & 15 & 0.38 & 8 & 3 & 3 & 1 & 6.79 \\
\hline Apr. & 18 & 0.45 & 8 & 5 & 4 & 1 & 8.14 \\
\hline May. & 21 & 0.53 & 10 & 6 & 3 & 2 & 9.50 \\
\hline Jun. & 25 & 0.63 & 12 & 6 & 4 & 3 & 11.31 \\
\hline Jul. & 26 & 0.65 & 15 & 7 & 3 & 1 & 11.76 \\
\hline Aug. & 27 & 0.68 & 18 & 5 & 3 & 1 & 12.22 \\
\hline Sep. & 25 & 0.63 & 12 & 7 & 5 & 1 & 11.31 \\
\hline Oct. & 15 & 0.38 & 7 & 3 & 4 & 1 & 6.79 \\
\hline Nov. & 14 & 0.35 & 7 & 4 & 3 & - & 6.33 \\
\hline Dec. & 12 & 0.30 & 6 & 4 & 1 & 1 & 5.43 \\
\hline Total & 221 & 0.46 & 115 & 54 & 40 & 12 & \\
\hline$\%$ & & & 52.04 & 24.43 & 18.10 & 5.43 & \\
\hline
\end{tabular}

*40 Traps /Month, ** Rodent index $=$ no. of trapped rodents/no. of trap nights

Table 2: Ectoparasite indices on indoors collected rodents from at east of lakes Ismailia Governorate over year 2010:

\begin{tabular}{|c|c|c|c|c|c|c|}
\hline Rodent sp. & $\begin{array}{l}\text { Rodents } \\
\text { number }\end{array}$ & $\begin{array}{c}\text { Ectoparasites } \\
\text { number }\end{array}$ & $\begin{array}{c}\text { Ectoparasites } \\
\text { Indices }\end{array}$ & $\begin{array}{c}\text { Ectoparasite } \\
\text { species }\end{array}$ & $\begin{array}{c}\text { Ectoparasites } \\
\text { number }\end{array}$ & $\begin{array}{l}\text { Ectopara- } \\
\text { site/rodent }\end{array}$ \\
\hline M. musculus & 115 & 215 & 1.087 & $\begin{array}{l}\text { X. cheopis }(\mathrm{F} .) \\
P . \text { spinulosa }(\mathrm{L} .)\end{array}$ & $\begin{array}{c}163 \\
52\end{array}$ & $\begin{array}{c}1.4 \\
0.45\end{array}$ \\
\hline $\begin{array}{l}\text { R. } r . \\
\text { Frugivorous }\end{array}$ & 54 & 238 & 4.41 & $\begin{array}{l}\begin{array}{l}\text { X. cheopis } \\
\text { P. spinulosa }\end{array} \text { (L.) } \\
\begin{array}{ll}\text { L. nuttalli } & \text { (M.) } \\
\text { O. bacoti } & \text { (M.) }\end{array}\end{array}$ & $\begin{array}{c}134 \\
43 \\
47 \\
14\end{array}$ & $\begin{array}{l}2.5 \\
0.8 \\
0.9 \\
0.3\end{array}$ \\
\hline $\begin{array}{l}R . r . \\
\text { alexandrinus }\end{array}$ & 40 & 187 & 4.68 & $\begin{array}{l}\text { X. cheopis }(\mathrm{F} .) \\
\text { P. spinulosa }(\mathrm{L} .) \\
\text { L. nuttalli (M.) } \\
\text { D. gallinae }(\mathrm{M} .) \\
\text { E. stabularis }(\mathrm{M})\end{array}$ & $\begin{array}{c}118 \\
17 \\
15 \\
29 \\
8\end{array}$ & $\begin{array}{c}2.95 \\
0.43 \\
0.38 \\
0.73 \\
0.2\end{array}$ \\
\hline $\begin{array}{l}R . \\
\text { norvigicus }\end{array}$ & 12 & 125 & 10.42 & $\begin{array}{l}\text { X. cheopis (F.) } \\
\text { C. segnis (F.) } \\
\text { P. spinulosa (L.) } \\
\text { L. nuttalli (M.) } \\
\text { O. bacoti (M.) } \\
\text { D. gallinae (M.) }\end{array}$ & $\begin{array}{c}44 \\
5 \\
38 \\
9 \\
10 \\
19\end{array}$ & $\begin{array}{l}3.67 \\
0.42 \\
3.17 \\
0.74 \\
0.83 \\
1.58 \\
\end{array}$ \\
\hline
\end{tabular}

F. $=$ Fleas $\quad$ L. $=$ Lice $\quad$ M. $=$ Mites $\quad$ T. $=$ Ticks 
A total of 177 rodents were captured from outdoor. Out of them M. musculus $(\mathrm{n}=4,2.3 \%)$, R. frugivorous $(\mathrm{n}=29$, $16.43 \%), \quad R$. alexandrinus $\quad(\mathrm{n}=37$, $20.9 \%), R$. norvegicus $(\mathrm{n}=36,20.3 \%)$, G. pyramidum $(\mathrm{n}=67,37.9 \%)$ and $J$. jaculus $(\mathrm{n}=4,2.3 \%)$. The commonest rat was G. pyramidum, significant temporal variation were recorded in the rodent densities captured from outdoors $(\mathrm{F}=74.05, \mathrm{P}<0.001)$. The maximum rat index $(0.58 \mathrm{rat} / \mathrm{trap})$ was recorded in June while the minimum (0.13 rat/trap) was recorded in January.

A total of 984 ectoparasites were recovered from different rat species captured from outdoors; these were six fleas species $(n=410,41.7 \%)$, one louse species $(n=100,10.2 \%)$; six mites species $(n=400,40.7 \%)$ and immature sta- ges of two ticks species $(n=74,7.5 \%)$. The maximum flea indices $(2.62,2.48$ \& $2.06 \mathrm{flea} / \mathrm{rat}$ ) were recorded on $X$. cheopis on $R$. alexandrinus, $R$. frugivorous and $R$. norvigicus respectively. The louse, $P$. spinulosa showed maximum lice' index; 1.2 louse/rat on $R$. norvigicus. The maximum mites' indices $(1.97,1.88 \mathrm{mite} / \mathrm{rat})$ were recorded for L. nuttalli on $R$. frugivorous and $O$. bacoti on $G$. pyramidum respectively. Immature tick stages were recorded only on $G$. pyramidum and $J$. jaculus with maximum ticks index for Hyalom$m a$ sp. (1.0 tick/rat) on the latter. The general indices of all ectoparasites recovered from outdoors' rodents were significantly higher than the indoors' ones $(\mathrm{F}=4.772, \mathrm{P}=0.039)$.

Table 3: Monthly abundance of outdoors collected rodents from at east of lakes, Ismailia Governorate over year 2010:

\begin{tabular}{|c|c|c|c|c|c|c|c|c|c|}
\hline \multirow[b]{2}{*}{ Month } & \multirow[b]{2}{*}{$\begin{array}{l}\text { No. } \\
\text { Rodent }\end{array}$} & \multicolumn{7}{|c|}{ Rodent species } & \multirow[b]{2}{*}{$\begin{array}{c}\% \\
\text { Species }\end{array}$} \\
\hline & & $\begin{array}{l}\text { Rodent } \\
\text { Index }\end{array}$ & $\begin{array}{c}\text { M. } \\
\text { musculus }\end{array}$ & $\begin{array}{c}R . r . \\
\text { frugivorous }\end{array}$ & $\begin{array}{c}R . r . \\
\text { alexandriuns }\end{array}$ & $\begin{array}{c}R . \\
\text { norvigicus }\end{array}$ & $\begin{array}{c}G . \\
\text { pyramidum }\end{array}$ & $\begin{array}{c}J . \\
\text { jaculus }\end{array}$ & \\
\hline Jan. & 5 & 0.13 & - & 2 & 2 & 1 & - & - & 2.82 \\
\hline Feb. & 7 & 0.18 & - & 2 & 2 & 2 & 1 & - & 3.95 \\
\hline Mar. & 11 & 0.28 & - & 1 & 2 & 2 & 6 & - & 6.21 \\
\hline Apr. & 14 & 0.35 & - & 2 & 2 & 4 & 5 & 1 & 7.91 \\
\hline May. & 18 & 0.45 & 1 & 2 & 3 & 3 & 8 & 1 & 10.17 \\
\hline Jun. & 23 & 0.58 & 1 & 2 & 2 & 4 & 12 & 2 & 12.99 \\
\hline Jul. & 22 & 0.55 & - & 5 & 4 & 5 & 8 & - & 12.4 \\
\hline Aug. & 20 & 0.50 & - & 3 & 6 & 4 & 7 & - & 11.3 \\
\hline Sep. & 21 & 0.53 & - & 4 & 6 & 4 & 7 & - & 11.9 \\
\hline Oct. & 16 & 0.40 & 1 & 3 & 3 & 3 & 6 & - & 9.04 \\
\hline Nov. & 12 & 0.30 & - & 2 & 3 & 2 & 5 & - & 6.78 \\
\hline Dec. & 8 & 0.20 & 1 & 1 & 2 & 2 & 2 & - & 4.52 \\
\hline Total & 177 & & 4 & 29 & 37 & 36 & 67 & 4 & \\
\hline$\%$ & & & 2.3 & 16.4 & 20.9 & 20.3 & 37.9 & 2.3 & \\
\hline
\end{tabular}

\section{Discussion}

As regards the indoor results, four species of rodents were collected, Norway rat, $R$. norvegicus, the grey bellied rat $R$. r. alexandrinus, whitebellied rat, $R$. $r$. frugivorous and house mouse $M$. musculus. The latter was the commonest species at the new settlements, west of Ismailia Governorate. Rat species captured outdoors had only two more species, G. pyramidum and $J$. jaculus. Gerbillus pyramidum was the most dominant species collected from outdoor. 
Table 4: Indices of ectoparasite species infesting rodents collected from outdoors at east of lakes, Ismailia Governorate, over year 2010:

\begin{tabular}{|c|c|c|c|c|c|c|}
\hline $\begin{array}{l}\text { Rodent } \\
\text { Species }\end{array}$ & $\begin{array}{l}\text { No. of } \\
\text { rodents }\end{array}$ & $\begin{array}{c}\text { No. of } \\
\text { ectoparasites }\end{array}$ & $\begin{array}{c}\text { Ectoparasites } \\
\text { Indices }\end{array}$ & $\begin{array}{c}\text { Ectoparasite } \\
\text { species }\end{array}$ & $\begin{array}{c}\text { No. of } \\
\text { Ectoparasites }\end{array}$ & $\begin{array}{l}\text { Ectoparasite } \\
\text { /Rodent }\end{array}$ \\
\hline $\begin{array}{l}\text { M. muscu- } \\
\text { lus }\end{array}$ & 4 & 6 & 1.5 & $\begin{array}{ll}\text { X. cheopis } & \text { (F.) } \\
P . \text { spinulosa } & \text { (L.) } \\
\text { O. bacoti } & \text { (M.) }\end{array}$ & $\begin{array}{l}3 \\
1 \\
2\end{array}$ & $\begin{array}{l}0.75 \\
0.25 \\
0.50\end{array}$ \\
\hline $\begin{array}{c}R . r . \\
\text { frugivorous }\end{array}$ & 29 & 174 & 5.07 & $\begin{array}{lr}\text { X. cheopis } & \text { (F.) } \\
\text { X. ramesis } & \text { (F.) } \\
\text { P. spinulosa } & \text { (L.) } \\
\text { L. nuttalli } & \text { (M.) } \\
\text { O. bacoti } & \text { (M.) }\end{array}$ & $\begin{array}{l}72 \\
15 \\
17 \\
57 \\
13\end{array}$ & $\begin{array}{l}2.48 \\
0.52 \\
0.59 \\
1.97 \\
0.45\end{array}$ \\
\hline $\begin{array}{l}R . r . \text { alex- } \\
\text { andrinus.r. }\end{array}$ & 37 & 207 & 5.59 & $\begin{array}{lc}\text { X. cheopis } & \text { (F.) } \\
\text { X. ramesis } & \text { (F.) } \\
\text { P. irritans } & \text { (F.) } \\
\text { P. spinulosa } & \text { (L.) } \\
\text { L. nuttalli } & \text { (M.) } \\
\text { D. gallinae } & \text { (M.) } \\
\text { E. stabularis } & \text { (M.) }\end{array}$ & $\begin{array}{l}97 \\
18 \\
13 \\
38 \\
18 \\
12 \\
11\end{array}$ & $\begin{array}{l}2.62 \\
0.49 \\
0.35 \\
1.03 \\
0.49 \\
0.32 \\
0.30\end{array}$ \\
\hline $\begin{array}{l}\text { R. norvegi- } \\
\text { cus }\end{array}$ & 36 & 201 & 5.58 & $\begin{array}{ll}\text { X. cheopis } & \text { (F.) } \\
\text { C. segnis } & \text { (F.) } \\
\text { P. irritans } & \text { (F.) } \\
\text { P. spinulosa } & \text { (L.) } \\
\text { L. nuttalli } & \text { (M.) } \\
\text { O. bacoti } & \text { (M.) } \\
\text { D. gallinae } & \text { (M.) } \\
\end{array}$ & $\begin{array}{c}74 \\
9 \\
12 \\
44 \\
35 \\
17 \\
10\end{array}$ & $\begin{array}{c}2.06 \\
0.25 \\
0.33 \\
1.22 \\
1.0 \\
0.47 \\
0.28 \\
\end{array}$ \\
\hline $\begin{array}{c}G . \\
\text { pyramidum }\end{array}$ & 67 & 375 & 5.6 & $\begin{array}{lc}\begin{array}{l}\text { X. cheopis } \\
\text { X. ramesis }\end{array} \text { (F.) } \\
\text { P. irritans } & \text { (F.) } \\
\text { S. tripictinata } & \text { (F.) } \\
\text { N. sinaiensis } & \text { (F.) } \\
\text { L. nuttalli } & \text { (M.) } \\
\text { O.bacoti } & \text { (M.) } \\
\text { H. pontiger } & \text { (M.) } \\
\text { H. isabellinus } & \text { (M.) } \\
\text { Rhipicephalus }(\mathrm{T} .) \\
\text { Hyalomma } \text { sp. (T.) }\end{array}$ & $\begin{array}{c}37 \\
18 \\
17 \\
8 \\
7 \\
60 \\
126 \\
14 \\
18 \\
27 \\
43 \\
\end{array}$ & $\begin{array}{l}0.55 \\
0.27 \\
0.25 \\
0.12 \\
0.10 \\
0.90 \\
1.88 \\
0.21 \\
0.27 \\
0.40 \\
0.64 \\
\end{array}$ \\
\hline J.jaculus & 4 & 21 & 5.25 & $\begin{array}{ll}\begin{array}{l}\text { X. ramesis } \\
\text { P. irritans }\end{array} \text { (F.) } \\
\text { S. tripictinata }(\mathrm{F} .) \\
\begin{array}{l}\text { O. bacoti } \\
\text { E. stabularis }\end{array} \text { (M.) } \\
\text { Hyalomma sp.(T.) }\end{array}$ & $\begin{array}{l}5 \\
2 \\
3 \\
4 \\
3 \\
4\end{array}$ & $\begin{array}{c}1.25 \\
0.50 \\
0.75 \\
1.0 \\
0.76 \\
1.0 \\
\end{array}$ \\
\hline
\end{tabular}

$$
\text { F. }=\text { Fleas } \quad \text { L. }=\text { Lice } \quad \text { M. }=\text { Mites } \quad \mathrm{T} .=\text { Ticks }
$$

Table 5: Total ectoparasites associated with rodents both indoors and outdoors at east of lakes, Ismailia Governorate, Egypt during 2010:

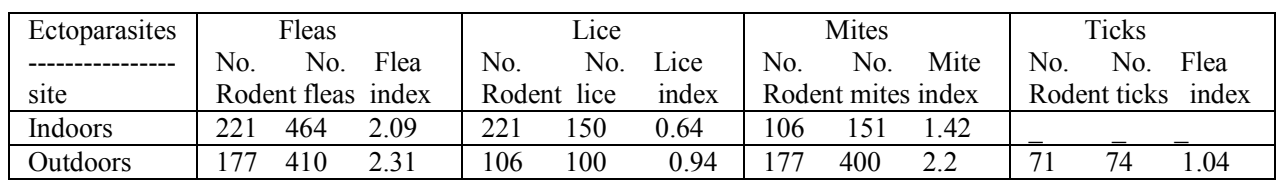


The domestic rodent species in Egypt were reported by several authors; Mahdi et al. (1971) found that $R$. norvegicus was the dominant species at Suez area. Morsy et al. (1986) identified five species of rodents in Suez Governorate (G.) they were, M. musculus, R. rattus, $R$. norvegicus, Acomys cahirinus and Sekeetamys calurus. In Alexandria city Morsy et al. (1988) found that $R$. norvegicus was commonest than $R$, alexandrinus. It is worthy to refer to the role played by these species in the transmission and dissemination of serious pathogens to man. The usual infestation of plague in rats occurs in the Norway rat and less frequently in roof rat and house mouse Soliman et al. (2010). Allam et al. (2002) identified common domestic rodents in Damietta and Qualyobia Gs; they were $R$. alexandrinus, $R$. frugivorus and $R$. norvegicus. Shoukry et al. (2006) in three different habitats (domestic, peridomestic $\&$ wild rodents) identified $R$. norvegicus, $R$. alexandrinus, $R$. frugivorus, $M$. musculus, A. russatus, Meriones sacramenti and G. pyramidum. Mahmoud et al. (2008) found $R$. norvegicus, $R$. alexandrinus, $R$. frugivorus, M. musculus, A. cahirinus in Suez, Menoufia, Giza, Demiatta and Beni-Suef Governorates. $R$. norvegicus showed higher frequency in Suez, Giza and Damietta Governorates. On the other hand, $R$. alexandrinus and M. musculus were the most dominant species in Menoufia and Beni-Suef respectively. They also found that the frequency of males $R$. norvegicus were significantly higher than females in all governorates.
In the present study the highest rat indices were 0.68 and 0.58 at indoors and outdoors respectively. Previous records of rat indices in Egypt ranged between 0.100 (Morsy et al, 1982) and 0.847 (Morsy et al, 1987) in Ismailia G. However, Soliman et al. (2001b) in Sharkia G. found relatively lower rat index 0.086 was recorded. The variations in rat indices reflect the degree of application of control measures to rodents in different study areas. Doubtless the areas with relatively high rat indices still need more applications of intensive control measures. In the present study, $R$. norvegicus was the least indoors abundant species. This may partly be attributed to the unsuitable conditions inside houses to be invaded with this species. The houses in the study area were mostly built of red bricks and had tile- covered floor which were not matching with the strong tendency of this species for burrowing (Brooks and Rowe, 1987). The significant increase in rat indices during summer months both indoors and outdoors may be due to the increased availability of food during summer when seed and grains are stored inside houses and in cereal granaries near houses which might allow an increase in pregnancy rates during summer months. High rodent indices were recorded in different areas in spring (Abdel-Gawad and Maher, 1987), summer (Zeese et al, 1990), autumn (Shoukry et al,1986), winter (Shoukry et al, 1987a), but without clear season-based changes in rodent index (Soliman et al, 2001b). 
The present study reported four flea species; $X$. cheopis, $X$. ramesis, $C$. segnis and $P$. irritans. The maximum flea indices were recorded for $X$. cheopis both indoors (3.67 flea/rat) and outdoors $(2.62,2.48,2.06$ flea/rat). In previous studies, the oriental rat flea $X$. cheopis was the predominant ectoparasite of rodents in Ismailia Governorate (Shoukry et al, 1987). Flea species, $X$. cheopis, P. irritans, C. felis, C. segnis and Echidnophage gallinacea were infesting different rodent species in Suez G. (Morsy et al, 1986). The maximum flea indices were recorded on $R$. norvegicus, $R$. frugivorous and $R$. alexandrinus. These species are characterized by relatively larger size compared to other species. Larger hosts generally have greater carrying capacities than smaller hosts belonging either to the same or different species (Phillips, 1966; Fahmy et al, 1971; Bu-delov et al, 1989; Soliman et al, 2001 a,b). In addition to differences in host body size variations in the general indices of fleas between rat species might be related to differences in, skin and hair characters of hosts as well as differences in the habit of fleas themselves (Soliman et al, 2001a).

Xenopsylla cheopis were associated with human settlements (Suntsov et al, 1997). In Burma, epizootics among rodents usually occurred when the $X$. cheopis general index exceeded 0.5 and human cases appeared when the general index was about 1.0 (Thaung et al, 1975). Unfortunately, the $X$. cheopis general indices in study sites reached 3.67 in $R$. norvigicus and 2.62 in $R$. alexandrinus. $X$. cheopis is considered the primary epidemic and enzootic vector of murine typhus (Rickettsia typhi). Antibodies against $R$. typhi were detected in $71 \%$ of Rattus spp. in Sharkia G. (Soliman et al, 2001a). Recorded percentages of rats positive against antibodies of $R$. typhi in Egypt were $47.3 \%$ in Rattus spp. collected from El Arish (Shoukry et al, 1991), 21.33\% and $7.4 \%$ in $R$. rattus collected from different rural areas and urban Cairo (Hoogstraal, 1986). Zoonotic foci of flea disease like plague was not found in the study immediate vicinity of site, the disease persisted in a commensal rat-flea cycle in and around human settlement (Suntsov et al, 1997), but ElBahnasawy et al. (2012a) raised a question about plague as a problem in Egyptians returning back from Libya.

The present study reported six mites' species. The maximum mite indices (1.97, $1.88 \& 1.58 \mathrm{mite} / \mathrm{rat})$ were $\mathrm{rec}-$ orded for L. nuttali on $R$. frugivorous, $O$. bacoti, on G. pyramidum captured from outdoors and $D$. galinae on $R$ .norvegicus captured from indoors. The domestic rat mite L. nuttali is a parasite of rodents mainly of the genus Rattus. It has been reported in some Egyptian Governorates as South Sinai (Shoukry et al, 1993; El Kady et al, 1998) and Suez Governorate (Younis et al, 1995). The tropical rat mite $O$. bacoti infests rats and man nearly allover the world. It has been reported in many Egyptian governorate as Ismailia G. (Morsy et al, 1982), Sharkia G. (Zeese et al, 1990), Suez G. (Younis et al, 1995), Suez Canal Zone (El Kady et al,1995), Saint Catherine area (El Kady et al, 1998) and Dakahlia G. (El Kady et al, 
2007). This species has a cosmopolitan distribution and occurs associated with mice, rat and other species found in both tropical and temperate areas of the world. It frequently attracts persons living in rodent infested buildings and its bites may produce irritation and sometimes painful dermatitis or mite allergy at the puncture site around particularly in children (Dove and Shelmir, 1933). The chicken mite D. gali$n a e$ is also a cosmopolitan species parasitizes not only chicken but also many species of wild and domestic birds. It attracts man, causing painful skin irritation by its bites (Berndt, 1952; El Kady el al, 1995). Lesions resembled those of scabies Urticaria papulosa, and impetigo- like dermatitis have been reported in children (Frenken, 1962). St. louis encephalitis virus was isolated on several occasions from chicken mites (Hammon and Reeves, 1945) and western equine encephalomyelitis virus has been recovered from $D$. americanus Ewing, a species closely related to D. galinae (Miles et al, 1951). It is one of the avian spirochaetosis vectors (Seddon, 1951). As a parasite of chicken, D. galinae causes serious illness or death through exsanguinations. Apart from all the infectious diseases transmitted or caused by mites, atopic dermatitis (Morsy et al, 1994; Kenawi et al, 1993) and allergic respiratory diseases (Morsy et al, 1994, 1995) was attributed to mites' infestation particularly among Egyptian children.

As to lice, the species recovered was $P$. spinulosa, with maximum index; 1.22 louse/rat on the outdoors captured $R$. norvigicus. This species was report- ed on several rodent species in Egypt (Morsy et al, 1982, 1986; El Kady et al, 2007; Soliman et al, 2001a). Biting lice or Polyplax spp. can transmit rickettsia among rats (Mooser et al, 1931) but don't feed on man (Soulsby, 1978).

The ticks were very rare in the study reported only on G. pyramidum and $J$. jaculus. Tick indices were 0.40 for $R h i-$ picephalus sp. on $G$. pyramidum and 0.64, 1.0 for Hyalomma sp. on G. pyramidum and $J$. jaculus respectively. Rhipicephalus sp. is mainly a dog tick, but recorded on rodents by many authors (Cooley, 1946; Theiler, 1950; Morsy et al, 1982, 1984, 1993). Species of genus Rhipicephalus are large, difficult to differentiate and are important vectors of infectious diseases. They transmit canine, bovine and equine piroplasmosis or biliary fever, dog Hepatozoon, Coxiella burnetti, Rickettsia conori, $R$. rickettsii, Borrelia hispanica, Theileria sp. and viral diseases of sheep (Zumpt, 1958; Arthur, 1962). Hyalomma spp. is vector of many pathogenic agents as Babesia sp., Theileria sp., C. burnetti, $R$. bovis, $R$. conori \& viral hemorrhagic fever (El-Bahnasawy et al, 2012b). Commensal rodents infested by ticks have been implicated as reservoirs of rickettsial diseases in the reclaimed land of North Sinai (Shoukry et al, 1991). Besides, B. microti infection was detected among rats trapped in Ismailia and Port Said Gs (El Bahrawy et al, 1993). Babesia sp. was observed in about one third of rodent trapped in both Bilbeis and Salehiya (Farid et al, 1997), infection was reported in an Egyptian boy and his pet dog (El-Bahnasawy and Morsy, 2008). 
The study area has been subjected to rapid environmental changes as a result of exploitation by an increasing number of humans and domestic animals. The area as a part of North Sinai desert was inhibited before with wild rodents (Shoukry et al, 1991). All wild species were more or less eliminated except $G$. pyramidum the outdoors most dominant species $(n=67,37.9 \%)$. It is the commonest wild rodent species recorded in most Egyptian deserts near housing (Morsy et al, 1988). However, the commensal rodents which are widely distributed in the Nile Delta and Nile Valley are rapidly spreading in the study area and have been reported both indoors and outdoors. The aggressive nature of $R$. norvigicus helps to attain its prevalence indoors and outdoors with G. pyramidum. However, its prevalence did not prevent other commensals ones outdoors.

\section{Conclusion}

The results showed wide abundance of rodents and their ectoparasites. Unfortunately the presence of both together in newly reclaimed area suggesting amplification of transmitting zoonosis not found before in the Nile Delta and Nile Valley which constitute a potential threat to the socio-economic progress of such areas. This fact should be considered by the Public Health and Veterinary Authorities

\section{References}

Abdel Gawad, KH, Maher, AA, 1987: Seasonal distribution of rodent species and their associated ectoparasites in the new cultivated land. Egypt. J. Wildlife Nat. Resour. 9:1-11.
Abdou, AH, Samaan, M, 1962: Egyptian rodent and their public health importance. J. Arab Vet. Med Assoc. 22, 4:403-31.

Allam, KAM, Shalaby, AA, Ashour, MA, 2002: Seasonal distribution of fleas infesting rodents in various Egyptian eco-geographical areas and their susceptibility to malathion. J. Egypt Soc. Parasitol. 32, 2:405-14.

Arthur, DR, 1962: Ticks and Disease. Oxford, Bergamot Press.

Baker, EW, Evans, TM, Gould, DJ, Hull, WB, Keegan, HC, 1956: A Manual of the Mites of Medical or Economic Importance. New York, A Technical Publication of the National Pest Control Association, Inc., New York.

Berndt, WL, 1952: The chicken mite attacking children. J. Econ. Entomol, 45:1098-010.

Brooks, JE, Rowe, FP, 1987: Commensal Rodent Control. Vector Control Series, Rodents, Training and Information Guide: Vector Biology and Control Division, WHO, Switzerland.

Burdelove, LA, Zhubanzarov, IZh, Rudenchis NF, 1989: The size of small mammals and number of fleas parasitizing on them. Med. Parasitol. Bolezni 87:42-5.

El Gindy, MS, Morsy, TA, Bebars, MA, Sarwat, MA, Arafa, MAS, et al, 1987: Rodent as reservoirs of zoonotic intestinal helminthes in Suez Canal Zone with possible immunological changes. J. Egypt. Soc. Parasitol. 17, 1: 259-74.

El Kady, GA El Shazly, AM, Mikhail, MW, Bahgat, IM, 2007: Ectoparasites of commensal rodents in Talkha 
center, Dakahlia Governorate, Egypt. J. Egypt. Soc. Parasitol. 37, 3:825-33.

El Kady, GA, Makled, KM, Morsy, TA, Morsy, ZS, 1998: Rodent, their seasonal activity, ecto- and blood-parasites in Saint Catherine area, South Sinai Governorate. J. Egypt. Soc. Parasitol. 28. 3:815-26.

El Kady, GA, Shoukry, A, Ragheb, D A, El Said, AM, Habib, KSM, Morsy, TA, 1995: Mites (Acari) infesting commensal rats in Suez Canal zone, Egypt. J. Egypt. Soc. Parasitol. 25, 2: 417-25.

El-Bahnasawy, MM, Morsy, TA, 2008: Egyptian human babesiosis and general review. J. Egypt. Soc. Parsitol. 38, 1:265-72.

El-Bahnasawy, MM, Ahmad, GMS, Abdel-Fattah, MA, Gaber, WAI, Morsy, TA, 2012a: Is plague a problem in the Egyptians returning back from Libya? J. Egypt. Soc. Parasitol. 42, 2:329-48.

El-Bahnasawy, MM, Sabah, AAA, Saleh, HAA, Morsy, TA, 2012b: The tick-borne Crimean-Congo hemorrhagic fever in Africa, Asia, Europe, and America: What about Egypt? J. Egypt. Soc. Parrasitol. 42, 2:373-84.

El-Bahrawy, AAF, Hegab, AMI, EI Kady, GA, Abdel-Azeem, MI, 2008: Field studies on commensal rodents at El-Ibrahemia district, Sharkia Governorate. Egypt. J. Appl. Sci. 23, 5:23043.

El-Bahrawy, AF, Nafei, SM, Morsy, TA, Farrag, AMK, 1993: Natural $B a-$ besia infection sought in black and Norway rats. J. Egypt. Soc. Parasitol. 23:349-55.
Fahmy, MAM, Mahdi, AH, Arafa M S, 1971: Some observations on lice (Anoplura) and mite (Acarina) infesting rats and mice in Egypt. Egypt. J. Egypt. Soc. Parasitol., 1:111-9.

Farid, HA, El Kady, GA, Ahmed SE, 1997: Babesia (Piroplasmorida: Babesiidae) and associated tick and rodent hosts in a newly established agricultural system in Egypt. J. Egypt. Ger. Soc. Zool 22, E:47-67.

Frenken, JH, 1962: Dermanyssus gallinae (D. avium). Dermatoloia, 125: 322-30.

Hammon, WM, Reeves, WC, 1945: Recent advances in the epidemiology and of the arthropod borne virus encephalitides. Amer. J. Pub. Hlth. 35:9941004.

Hoogstraal, H, 1956: African Ixodidea Vol. 1; Ticks of the Sudan, Research Report NAMRU-3, Cairo, Egypt.

Hoogstraal, H, 1986: Viruses. rickettsias, spirochetes, leishmaniasis and other organisms of proven or potential public health importance infecting Egyptian rodents. Proc. $2^{\text {nd }}$ Symp.: Recent Adv. Rodent Cont. Kuwait.

Hubbard, CA, 1947: Fleas of Western North America: The Iowa State College Press, USA.

Kenawi, MZ, Morsy, TA, Abdalla, $\mathrm{K}$ F, El Hady, HM, 1993: Treatment of human scabies by sulfur and permethrin. J. Egypt. Soc. Parasitol. 23, 3:6916.

Lewis, RE, 1967: The fleas (Siphonaptera) of Egypt: an illustrated and annotated key. J. Parasitol. 53, 4:863-85.

Mahdi, AH, Arafa, MS, Ismail, SM, 1971: A preliminary survey of domes- 
tic rodents and fleas in newly developed area (Tahrir Province), U.A.R. J. Egypt. Pub. Hlth. Assoc. 46:33-44.

Mahmoud, KA, Metwally, AM, Mangoud, AAH, Mohamed, AS, 2008: Survey of commensal rodents and their fleas in different Egyptian Agroecosystems. J. Agricul. Res. 6: 2105-16.

Miles, VI, Hewitt, BF, Gorier, R, Cockburn, T, 1951: Encephalitis in Midwest. V- Western Equine encephalitis virus recovered from mites Dermanyssus americanus Ewing. Proc. Soc. Exp. Biol. Med. 77:395-6.

Mooser, H, Castaneda, MR, Zinsser, H, 1931: The transmission of the virus of Mexican typhus from rat to rat by Polyplax spinulosa. J. Exp. Med. 54: 567-75.

Morsy, TA, Abo El-Ela, RG, El Gozamy, BMR, 1988: The commensal rodents and their flea fauna in Alexandria City, Egypt. J. Egypt. Soc. Parasitol. 18, 1:11-28.

Morsy, TA, Bassili, WR, Fayad, ME, El Okbi, LM, Saleh, MSM, 1987: Rodent in relation to cutaneous leishmaniasis in North Sinai Governorate, Egypt. J. Egypt. Soc. Parasitol. 17, 2: 427-35.

Morsy, TA, El Kady, GA, Salama, M MI, Sabry, AHA, 1993: The seasonal abundance of Gerbillus pyramidum and their flea ectoparasites in Al Arish, North Sinai Governorate, Egypt. J. Egypt. Soc. Parasitol. 23, 1:269-76.

Morsy, TA, El Said, AM, Salama, M MI, Arafa, MAS, Younis, TA, et al, 1995: Four species of house dust mites recovered from houses of patients with allergic respiratory diseases. J. Egypt. Soc. Parasitol. 25, 1:195-206.
Morsy, TA, Fayad, ME, Abou-Shady, AKA, Yousef, NSH, 1986: Ectoparasites of rodents in Suez Governorate, with special reference to fleas, J. Egypt Soc. Parasitol. 16, 2: 457-68.

Morsy, TA, Ibrahim, BB, Haridy, F M, Rifaat, MMA, 2000: Trichinella encysted larvae in slaughtered pigs in Cairo (1995-1999). J. Egypt. Soc. Parasitol. 30, 3:753-60.

Morsy, TA, Michael, SA, Bassili, W R, Saleh, MSM, 1982: Studies on rodents and their zoonotic parasites particularly Leishmania, in Ismailia Governorate, A.R. Egypt. J. Egypt. Soc. Parasitol.12, 2:565-83.

Morsy, TA, Schnur, L, Feinso, FM, Michael, SA, Saah, A, 1984: Natural leishmanial infections in Rattus norvegicus from Alexandria, Egypt. Abstracts: $4^{\text {th }}$ European Multi-colloquium of Parasitology, October (14-19), Turkey.

Morsy, TA, Zohdi, HW, Abdalla, K F, El Fakahany, AF, et al, 1994: Isolation of three species of mites from house dust of atopic dermatitis patients in Qualyobia Governorate, Egypt. J. Egypt. Soc. Parsitol. 24, 2: 323-32.

Osborn, DG, Helmy, I, 1980: The Contemporary and Mammals of Egypt (including Sinai), Fieldiana Zool. (New Series) 5:1-579.

Phillips, CJ, 1966: Some factors influencing incidence and degree of ectoparasitism of small mammals from Taiwan. J. Med. Entomol. 3:150-5

Reeves, WK, Loftis, AD, Szumlas, D E, Abbassy, MM, et al, 2007: Rickettsial pathogens in the tropical rat mite Ornithonyssus bacoti (Acari: Macronyssidae) from Egyptian rats (Rattus spp.). J. Exp. Appl. Acarol. 41:101-7. 
Rifaat, MA, Morsy, TA, Sadek, MS, Khalid, M, 1978: A review of toxoplasmosis in Egypt. J. Egypt. Soc. Parasitol. 8: 393-8.

Seddon, HR, 1951: Diseases of domestic animals in Australia. Part 3- Ticks and Mites infestation: Division of Veterinary Hygiene, Public Health Department and Commonwealth of Australia.

Shoukry, A, Morsy, TA, Abu-Hashish, T, El Kady, GA, 1986: Seasonal actives of two commensally rats and flea index in north Sinai Governorate, Egypt. J. Egypt. Soc. Parasitol. 16, 2: 385-92.

Shoukry, A, Morsy, TA, Farahat, A A, 1987: The seasonal abundance and the maturity of some rodent species in Ismailia Governorate, Egypt. J. Egypt. Soc. Parasitol. 17, 2:397-408.

Shoukry, A, Merdan, AI, El Kady, G A, 1991: The role of rodents as reservoirs for some diseases in new reclaimed areas in north Sinai. J. Egypt. Soc. Parasitol. 21, 2:513-9.

Shoukry, A, EI Kady, GA, Morsy, T A, Salama, MMI, 1993: Rodents and their arthropod ectoparasites in South Sinai Governorate, Egypt. J. Egypt. Soc. Parasitol. 23, 3:775-83.

Shoukry, NM, El-Naggar, MH, Darwish, AB, Soliman, BA, El-Sawaf, B M, 2006: Studies on rodent's role as reservoir hosts of leshmaniasis with special reference to their ectoparasites in Suez governorate. J. Egypt. Soc. Parasitol. 26, 1:93-106.

Soliman, S, Main, AJ, Marzouk, AS, Montasser, AA, 2001a: Seasonal studies on commensal rats and their ectoparasites in a rural area, Egypt: The relationship of ecto-parasites to spe- cies, locality and relation abundance of the host. J. Parasitol. 21, 3:545-53.

Soliman, S, Marzouk, A, Main, A, Montasser, A, 2001b: sex, size \& age of commensal rat hosts on their infestation parameters of ectoparasites in rural Egypt. J. Parasitol. 87, 6:1308-16.

Soliman, MI, Abd EI Halim, A, Mikhail, MW, 2010: Rodent borne diseases and their fleas in Menoufia Governorate, Egypt. J. Egypt. Soc. Parasitol. 40, 1:107-17.

Soulsby, EJ, 1978: Helminthes, Arthropods and Protozoa of Domesticated Animals. $6^{\text {th }}$ edition, English Language Book Society \& Bailliere: Tindall and Cassell Ltd.

Suntsov, VV, Huong, LT, Suntsova, NI, Gratz, NG, 1997: Plague foci in Viet-Nam: Zoological and parasitological aspects. Bull. WHO 75:117-23.

Thaung, U, Khai, M, Thein, M, 1975: Insecticide susceptibility of some vector fleas and mosquitoes in Burma Asian. J. Trop. Med. Publ. Hlth. 6:555.

Younis, TA, Fayad, ME, El-Hariry, MA, Morsy, TA, 1995: The interaction between Acari ectoparasites and rodents in Suez Governorate, Egypt J. Egypt. Soc. Parasitol., 25, 2:377-94.

Zeese, W, Khalaf, SA, Abou El-Ela, RG, Morsy, TA, 1990: Rodents and their ecto-parasites in Sharkia Governorate, Egypt. J. Egypt Soc. Parasitol. 20, 2:827-35.

Zumpt, F, 1958: A preliminary survey of the distribution and host specificity of ticks (Ixodoidea) in the Bechuanaland Proctorate. Bull. Entomol. Res. 49:201-23. 